University of Nebraska - Lincoln

DigitalCommons@University of Nebraska - Lincoln

Foreign exploration for Scirtothrips perseae Nakahara (Thysanoptera: Thripidae) and associated natural enemies on avocado (Persea americana Miller)

\author{
Mark S. Hoddle \\ University of California, Riverside, \\ Sueo Nakahara \\ Systematic Entomology Laboratory, USDA \\ Phil A. Phillips \\ University of California Cooperative Extension, Ventura, CA
}

Follow this and additional works at: https://digitalcommons.unl.edu/systentomologyusda

Part of the Entomology Commons

Hoddle, Mark S.; Nakahara, Sueo; and Phillips, Phil A., "Foreign exploration for Scirtothrips perseae Nakahara (Thysanoptera: Thripidae) and associated natural enemies on avocado (Persea americana Miller)" (2002). USDA Systematic Entomology Laboratory. 9.

https://digitalcommons.unl.edu/systentomologyusda/9

This Article is brought to you for free and open access by the Entomology Collections, Miscellaneous at DigitalCommons@University of Nebraska - Lincoln. It has been accepted for inclusion in USDA Systematic Entomology Laboratory by an authorized administrator of DigitalCommons@University of Nebraska - Lincoln. 


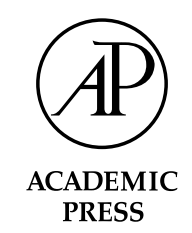

Biological Control 24 (2002) 251-265

Biological Control

www.academicpress.com

\title{
Foreign exploration for Scirtothrips perseae Nakahara (Thysanoptera: Thripidae) and associated natural enemies on avocado (Persea americana Miller)
}

\author{
Mark S. Hoddle, ${ }^{\mathrm{a}, *}$ Sueo Nakahara, ${ }^{\mathrm{b}}$ and Phil A. Phillips ${ }^{\mathrm{c}}$ \\ ${ }^{a}$ Department of Entomology, University of California, Riverside, CA 92521, USA \\ ${ }^{\mathrm{b}}$ Systematic Entomology Laboratory, PSI, Agricultural Research Service, USDA, 10300 Baltimore Avenue, Beltsville, MD 20705, USA \\ ${ }^{\mathrm{c}}$ University of California Cooperative Extension, 669 County Square Drive, Suite 100, Ventura, CA 93003, USA
}

Received 1 August 2001; accepted 7 March 2002

\begin{abstract}
Scirtothrips perseae Nakahara was discovered attacking avocados in California, USA, in 1996. Host plant surveys in California indicated that $S$. perseae has a highly restricted host range with larvae being found only on avocados, while adults were collected from 11 different plant species. As part of a management program for this pest, a "classical" biological control program was initiated and foreign exploration was conducted to delineate the home range of $S$. perseae, to survey for associated natural enemies and inventory other species of phytophagous thrips on avocados grown in Mexico, Guatemala, Costa Rica, the Dominican Republic, Trinidad, and Brazil. Foreign exploration efforts indicate that $S$. perseae occurs on avocados grown at high altitudes ( $>1500 \mathrm{~m})$ from Uruapan in Mexico south to areas around Guatemala City in Guatemala. In Costa Rica, S. perseae is replaced by an undescribed congener as the dominant phytophagous thrips on avocados grown at high altitudes $(>1300 \mathrm{~m})$. No species of Scirtothrips were found on avocados in the Dominican Republic, Trinidad, or Brazil. In total, 2136 phytophagous thrips were collected and identified, representing over 47 identified species from at least 19 genera. The significance of these species records is discussed. Of collected material $\sim 4 \%$ were potential thrips biological control agents. Natural enemies were dominated by six genera of predatory thrips (Aeolothrips, Aleurodothrips, Franklinothrips, Leptothrips, Scolothrips, and Karnyothrips). One genus each of parasitoid (Ceranisus) and predatory mite (Balaustium) were found. Based on the results of our sampling techniques, prospects for the importation of thrips natural enemies for use in a "classical" biological control program in California against S. perseae are not promising. (C) 2002 Elsevier Science (USA). All rights reserved.
\end{abstract}

Keywords: Aeolothrips; Ceranisus; Frankliniella; Franklinothrips; Neohydatothrips; Pseudanaphothrips; Scolothrips; Selenothrips; Thrips

\section{Introduction}

Scirtothrips perseae Nakahara (Thysanoptera: Thripidae) is a new pest of major economic significance in California avocado orchards. This insect was first discovered in June 1996 damaging fruit and foliage in Saticoy and Oxnard, Ventura County, CA, USA. By July 1997, infestations of $S$. perseae were north of the initial discovery area in San Luis Obispo County and south into San Diego County. Heavily infested orchards in Ventura County experienced $50-80 \%$ crop damage in

\footnotetext{
${ }^{*}$ Corresponding author. Fax: +909-787-3086.

E-mail address: mark.hoddle@ucr.edu (M.S. Hoddle).
}

1997 and fruit that suffered feeding damage was either unmarketable or downgraded in packinghouses (Hoddle and Morse, 1997, 1998). Crop losses in 1998 were estimated at \$7.6-\$13.4 million (US) from the combined effects of losses in quality and increased production costs associated with $S$. perseae management (Jetter, 1999). By May 1998, S. perseae infested 80\% of California avocado acreage (Hoddle et al., 1998) and currently $\sim 95 \%$ of fruit-bearing acreage have this pest.

Feeding damage by high densities of $S$. perseae larvae and adults on young leaves through the late fall to the end of spring can result in defoliation. However, the main source of economic loss attributable to $S$. perseae is scarring of immature fruit in spring by feeding thrips. Although scarring can be severe enough to render the 
entire fruit surface brown with a characteristic "alligator skin" appearance, these fruits can mature and flesh within damaged fruit is healthy, although the oil content may be reduced (Hoddle et al., 1998, 1999). Scarring to $5 \%$ of the fruit surface results in economic losses to growers (Phillips, 1997).

When initially discovered in California, S. perseae was an undescribed species that was new to science and its country of origin was unknown. Subsequent taxonomic work based on morphological comparisons determined that $S$. perseae was similar to Scirtothrips species endemic to Mexico and Central America rather than the known Scirtothrips species (e.g., citrus thrips, Scirtothrips citri [Moulton]) in North America (Nakahara, 1997).

Inoculative or "classical" biological control programs targeting pests of exotic origin involve prospecting for natural enemies within the pest's native range. Suitable natural enemies associated with the pest in its country of origin that clear quarantine and meet regulatory requirements after importation are eligible for release against the target pest in its new home range (Bellows and Legner, 1993; Rose and DeBach, 1990; Rosen and DeBach, 1992; Van Driesche and Bellows, 1996). The California avocado industry has had a long history of dependence on biological control as a cornerstone for pest management (Fleschner, 1954; Fleschner et al., 1955; McMurtry, 1992). Consequently, concern over crop damage caused by $S$. perseae prompted funding of a "classical" biological control program by the California Avocado Commission. Because S. perseae was an unknown entity when discovered in California, the first step in this biological control initiative was to locate and delineate the home range of $S$. perseae and to simultaneously prospect for natural enemies associated with this pest.

Five separate lines of evidence justified initial exploration for $S$. perseae in Mexico and Central America: (1) $S$. perseae is morphologically more similar to congeners from Mexico and Central America than North America and other areas of the world (Nakahara, 1997). (2) In 1971, two undescribed specimens of Scirtothrips were found on leaves of avocado plants intercepted from Oaxaca, Mexico, by APHIS-PPQ at the Port of San Diego, California. One damaged specimen examined initially varied slightly from $S$. perseae, but subsequent re-examination by $\mathrm{S}$. Nakahara indicated that it was within the acceptable range of morphological variation for this species. Later, a second thrips specimen from the same interception was located and both specimens are now considered to be the first known record of $S$. perseae. (3) Host plant surveys in California avocado orchards have found immature stages of $S$. perseae feeding only on avocados (see below for host plant survey results) and this was the only Scirtothrips species causing economic damage to avocados. (4) In California, $S$. perseae outbreaks occur during cool spring weather when avocados are developing young leaves and fruit. Immature leaves and fruit are used for feeding and oviposition by $S$. perseae and population outbreaks are closely synchronized with plant phenology induced by cool weather (Hoddle, 2002a). Furthermore, laboratorygenerated demographic growth statistics are highest for $S$. perseae reared on avocado leaves at low temperatures $\left(\leqslant 20^{\circ} \mathrm{C}\right)$, suggesting that this pest may have evolved closely with avocado to exploit nutritive and oviposition resources induced by low temperatures (Hoddle, 2002b). (5) Three geographic races of avocados are recognized; Persea americana var. drymifolia (Mexican race), $P$. americana var. guatemalensis (Guatemalan race), and $P$. americana var. americana (West Indian race). The Mexican and Guatemalan races evolved in high altitude regions of central Mexico and Guatemala, respectively. West Indian varieties are thought to have developed in humid lowland Pacific Ocean areas from Guatemala through Costa Rica. Humans transported avocados from these areas of origin, probably as seeds, into other areas of the Americas and elsewhere (Kopp, 1966; Mhameed et al., 1997; Popenoe, 1915; Scora and Bergh, 1990; Storey et al., 1986; Williams, 1977).

Laboratory and field studies in California have indicated that $S$. perseae may be closely adapted to avocado phenology. Host plant surveys showed a highly restricted host range (i.e., can complete entire life cycle only on avocado), suggesting that this pest may have evolved with $P$. americana somewhere in the natural range of this plant. This study provides the results of foreign exploration efforts for $S$. perseae, collection records for other species of phytophagous thrips and associated thrips natural enemies found on avocados in Mexico, Central America, the Caribbean, and South America.

\section{Materials and methods}

\subsection{Collecting and mounting techniques}

Plants were sampled for thrips and natural enemies by beating branches bearing young foliage or flowers, onto white plastic trays $(18 \mathrm{~cm} \times 30 \mathrm{~cm} \times 1.2 \mathrm{~cm})$. Adult and larval thrips (phytophages and predators), predatory mites, and parasitic Hymenoptera were removed from collecting trays with fine paint brushes and placed in labeled 2-ml plastic vials (Nalgene cryogenic vials 5000-0020, Nalge Company, Rochester, NY) containing a preservative (60\% ethanol (10 parts), glycerine (1 part), and glacial acetic acid (1 part) (Lewis, 1973).

Avocado trees were sampled in private residences, non-commercial and commercial orchards, botanic gardens, and along roadsides. Date and locality data were recorded along with GPS (Magellan Pioneer, 
Table 1

Collection records for Scirtothrips perseae and other thrips species collected from potential host plants growing in three avocado orchards in Southern California that were heavily infested with S. perseae in 1999

\begin{tabular}{|c|c|c|c|}
\hline Potential host plant & S. perseae adults present? & S. perseae larvae present? & Thrips species collected \\
\hline $\begin{array}{l}\text { Acca sellowiana } \\
\text { Annona cherimola }\end{array}$ & $\begin{array}{l}\text { Yes } \\
\text { Yes }\end{array}$ & $\begin{array}{l}\text { No } \\
\text { No }\end{array}$ & $\begin{array}{l}\text { Scirtothrips perseae } \\
\text { Scirtothrips perseae } \\
\text { Thrips tabaci Lindeman }\end{array}$ \\
\hline $\begin{array}{l}\text { Carica papaya } \\
\text { Chenopodium album }\end{array}$ & $\begin{array}{l}\text { No } \\
\text { No }\end{array}$ & $\begin{array}{l}\text { No } \\
\text { No }\end{array}$ & $\begin{array}{l}\text { Frankliniella occidentalis (Pergande) } \\
\text { Pseudanaphothrips achaetus } \\
\text { Aeolothrips kuwanaii Moulton }\end{array}$ \\
\hline Citrus spp. & No & No & $\begin{array}{l}\text { Frankliniella gossypiana Hood } \\
\text { Frankliniella occidentalis } \\
\text { Thrips tabaci }\end{array}$ \\
\hline $\begin{array}{l}\text { Coffea sp. } \\
\text { Cucurbita spp. }\end{array}$ & $\begin{array}{l}\text { No } \\
\text { Yes }\end{array}$ & $\begin{array}{l}\text { No } \\
\text { No }\end{array}$ & $\begin{array}{l}- \\
\text { Frankliniella occidentalis } \\
\text { Scirtothrips perseae } \\
\text { Thrips tabaci }\end{array}$ \\
\hline Cyphomandra betacea & No & No & $\begin{array}{l}\text { Frankliniella gossypiana } \\
\text { Frankliniella occidentalis }\end{array}$ \\
\hline $\begin{array}{l}\text { Eriobotrya japonica } \\
\text { Eucalyptus spp. } \\
\text { Ficus carica } \\
\text { Lycopersicon lycopersicum }\end{array}$ & $\begin{array}{l}\text { No } \\
\text { No } \\
\text { No } \\
\text { Yes }\end{array}$ & $\begin{array}{l}\text { No } \\
\text { No } \\
\text { No } \\
\text { No }\end{array}$ & $\begin{array}{l}- \\
- \\
- \\
\text { Frankliniella occidentalis } \\
\text { Scirtothrips perseae }\end{array}$ \\
\hline Macadamia sp. & No & No & $\begin{array}{l}\text { Frankliniella occidentalis } \\
\text { Scirtothrips inermis } \text { Priesner }\end{array}$ \\
\hline $\begin{array}{l}\text { Malus sp. } \\
\text { Malva purviflora }\end{array}$ & $\begin{array}{l}\text { No } \\
\text { No }\end{array}$ & $\begin{array}{l}\text { No } \\
\text { No }\end{array}$ & $\begin{array}{l}- \\
\text { Frankliniella occidentalis } \\
\text { Franklinothrips orizabensis }\end{array}$ \\
\hline Mangifera indica & Yes & No & $\begin{array}{l}\text { Scirtothrips inermis } \\
\text { Scirtothrips perseae }\end{array}$ \\
\hline Musa acuminata & Yes & No & $\begin{array}{l}\text { Frankliniella occidentalis } \\
\text { Scirtothrips perseae }\end{array}$ \\
\hline $\begin{array}{l}\text { Olea europaea } \\
\text { Nerium oleander } \\
\text { Nicotiana } \text { sp. }\end{array}$ & $\begin{array}{l}\text { No } \\
\text { No } \\
\text { No }\end{array}$ & $\begin{array}{l}\text { No } \\
\text { No } \\
\text { No }\end{array}$ & $\begin{array}{l}\text { Frankliniella occidentalis } \\
\text { Caliothrips fasciatus (Pergande) } \\
\text { Frankliniella occidentalis } \\
\text { Thrips tabaci }\end{array}$ \\
\hline $\begin{array}{l}\text { Passiflora edulis } \\
\text { Persea americana }\end{array}$ & $\begin{array}{l}\text { No } \\
\text { Yes }\end{array}$ & $\begin{array}{l}\text { No } \\
\text { Yes }\end{array}$ & $\begin{array}{l}\text { Frankliniella occidentalis } \\
\text { Scirtothrips perseae } \\
\text { Franklinothrips orizabensis }\end{array}$ \\
\hline $\begin{array}{l}\text { Persea indica } \\
\text { Prunus persica }\end{array}$ & $\begin{array}{l}\text { No } \\
\text { Yes }\end{array}$ & $\begin{array}{l}\text { No } \\
\text { No }\end{array}$ & $\begin{array}{l}- \\
\text { Frankliniella occidentalis } \\
\text { Scirtothrips perseae }\end{array}$ \\
\hline $\begin{array}{l}\text { Psidium } \mathrm{sp} . \\
\text { Punica granatum }\end{array}$ & $\begin{array}{l}\text { Yes } \\
\text { Yes }\end{array}$ & $\begin{array}{l}\text { No } \\
\text { No }\end{array}$ & $\begin{array}{l}\text { Scirtothrips perseae } \\
\text { Frankliniella occidentalis } \\
\text { Scirtothrips perseae }\end{array}$ \\
\hline Rubus sp. & No & No & $\begin{array}{l}\text { Frankliniella gossypiana } \\
\text { Frankliniella occidentalis } \\
\text { Thrips tabaci }\end{array}$ \\
\hline Sambucus caerulea & No & No & $\begin{array}{l}\text { Frankliniella occidentalis } \\
\text { Thrips australis (Bagnall) } \\
\text { Aeolothrips collaris } \text { Priesner } \\
\text { Aeolothrips kuwanaii Moulton }\end{array}$ \\
\hline Sonchus sp. & No & No & Frankliniella occidentalis \\
\hline
\end{tabular}


Table 1 (continued).

\begin{tabular}{llll}
\hline Potential host plant & S. perseae adults present? & S. perseae larvae present? & Thrips species collected \\
\hline & & & Aeolothrips collaris \\
Urtica dioica & No & No & - \\
Vaccinium corymbosum & No & No & - \\
Vitis sp. & Yes & No & Frankliniella occidentalis \\
& & & Scirtothrips perseae \\
\hline
\end{tabular}

Table 2

Phytophagous and predatory thrips found on avocados in Mexico

\begin{tabular}{|c|c|c|c|c|}
\hline Town or city & State & Elevation $(\mathrm{m})$ & GPS coordinates & Thrips species found \\
\hline Atlixco & Puebla & 2100 & - & $\begin{array}{l}\text { Frankliniella sp. nr. aureus Moulton } \\
\text { Scirtothrips perseae }\end{array}$ \\
\hline Ayutla & Oaxaca & 1897 & $\begin{array}{l}17^{\circ} 01.89 \mathrm{~N} \\
96^{\circ} 0.4 .56 \mathrm{~W}\end{array}$ & $\begin{array}{l}\text { Aeolothrips mexicanus Priesner } \\
\text { Frankliniella chamulae } \\
\text { Frankliniella occidentalis } \\
\text { Frankliniella } \text { sp. nr. occidentalis } \\
\text { Leptothrips mcconnelli } \\
\text { Neohydatothrips burungae } \\
\text { Scirtothrips aceri Moulton } \\
\text { Scirtothrips perseae }\end{array}$ \\
\hline Chilapa de Diaz & Oaxaca & 1592 & $\begin{array}{l}17^{\circ} 34.94 \mathrm{~N} \\
97^{\circ} 38.07 \mathrm{~W}\end{array}$ & $\begin{array}{l}\text { Caliothrips phaseoli } \text { (Hood) } \\
\text { Frankliniella } \text { sp. nr. bruneri Watson } \\
\text { Frankliniella cubensis } \text { Hood } \\
\text { Frankliniella } \text { sp. nr. cubensis } \\
\text { Frankliniella occidentalis } \\
\text { Frankliniella } \text { sp. runneri group (Morgan) } \\
\text { Franklinothrips vespiformis } \\
\text { Leptothrips mcconnelli } \\
\text { Leucothrips furcatus Hood } \\
\text { Neohydatothrips burungae } \\
\text { Scirtothrips perseae } \\
\text { Scirtothrips sp. } \\
\text { Scolothrips pallidus } \text { (Beach) }\end{array}$ \\
\hline Coatepec-Harinas & Mexico & 2000 & - & $\begin{array}{l}\text { Aeolothrips major Bailey } \\
\text { Frankliniella cubensis } \\
\text { Neohydatothrips burungae } \\
\text { Scirtothrips perseae }\end{array}$ \\
\hline Oaxaca & Oaxaca & 1635 & $\begin{array}{l}17^{\circ} 03.63 \mathrm{~N} \\
96^{\circ} 39.78 \mathrm{~W}\end{array}$ & $\begin{array}{l}\text { Frankliniella cubensis } \\
\text { Frankliniella fallaciosa } \text { Priesner } \\
\text { Franklinothrips vespiformis } \\
\text { Leptothrips mcconnelli } \\
\text { Neohydatothrips burungae }\end{array}$ \\
\hline Piste & Yucatan & 25 & $\begin{array}{l}20^{\circ} 41.79 \mathrm{~N} \\
88^{\circ} 35.13 \mathrm{~W}\end{array}$ & $\begin{array}{l}\text { Stephanothrips occidentalis Hood \& Williams } \\
\text { Pseudophilothrips sp. nr. perseae }\end{array}$ \\
\hline San Andres Huayapan & Oaxaca & 1587 & $\begin{array}{l}17^{\circ} 06.29 \mathrm{~N} \\
96^{\circ} 39.93 \mathrm{~W}\end{array}$ & $\begin{array}{l}\text { Frankliniella cephalica (Crawford) } \\
\text { Frankliniella cubensis } \\
\text { Frankliniella } \text { sp. nr. exigua Hood } \\
\text { Frankliniella gossypiana Hood } \\
\text { Frankliniella occidentalis } \\
\text { Frankliniella } \text { sp. nr. occidentalis } \\
\text { Frankliniella } \text { sp. runneri } \\
\text { Franklinothrips vespiformis } \\
\text { Leptothrips mcconnelli } \\
\text { Neohydatothrips burungae } \\
\text { Scirtothrips aceri } \\
\text { Scirtothrips citri } \\
\text { Scirtothrips perseae } \\
\text { Scirtothrips sp. } \\
\text { Scolothrips pallidus }\end{array}$ \\
\hline
\end{tabular}


Table 2 (continued).

\begin{tabular}{|c|c|c|c|c|}
\hline Town or city & State & Elevation $(\mathrm{m})$ & GPS coordinates & Thrips species found \\
\hline San Francisco la Chigolio & Oaxaca & 1644 & $\begin{array}{l}17^{\circ} 01.72 \mathrm{~N} \\
96^{\circ} 35.96 \mathrm{~W}\end{array}$ & $\begin{array}{l}\text { Frankliniella cephalica } \\
\text { Neohydatothrips burungae } \\
\text { Scirtothrips aceri } \\
\text { Scirtothrips citri (Moulton) } \\
\text { Scirtothrips sp. }\end{array}$ \\
\hline Tlalixtac & Oaxaca & 1580 & $\begin{array}{l}17^{\circ} 03.63 \mathrm{~N} \\
96^{\circ} 39.78 \mathrm{~W}\end{array}$ & $\begin{array}{l}\text { Frankliniella chamulae } \\
\text { Frankliniella } \text { sp. nr. bruneri } \\
\text { Frankliniella cubensis } \\
\text { Frankliniella } \text { sp. runneri group } \\
\text { Franklinothrips vespiformis } \\
\text { Karnyothrips flavipes (Jones) } \\
\text { Neohydatothrips burungae } \\
\text { Scirtothrips perseae } \\
\text { Scirtothrips sp. } \\
\text { Scirtothrips sp. nr. citri }\end{array}$ \\
\hline Uruapan & Michoacan & 2010 & $\begin{array}{l}19^{\circ} 25.83 \mathrm{~N} \\
102^{\circ} 04.51 \mathrm{~W}\end{array}$ & $\begin{array}{l}\text { Caliothrips fasciatus (Pergande) } \\
\text { Frankliniella brunnea Priesner } \\
\text { Frankliniella } \text { sp. nr. bruneri } \\
\text { Frankliniella cubensis } \\
\text { Frankliniella fallaciosa } \\
\text { Frankliniella insularis (Franklin) } \\
\text { Frankliniella occidentalis } \\
\text { Frankliniella } \text { sp. nr. bruneri } \\
\text { Frankliniella chamulae } \\
\text { Frankliniella } \text { sp. fulvipennis Moulton group } \\
\text { Franklinothrips orizabensis Johansen } \\
\text { Franklinothrips vespiformis } \\
\text { Haplothrips gowdeyi (Franklin) } \\
\text { Neohydatothrips burungae } \\
\text { Neohydatothrips tibialis Priesner } \\
\text { Scirtothrips perseae }\end{array}$ \\
\hline Valladolid & Yucatan & 30 & $\begin{array}{l}20^{\circ} 41.82 \mathrm{~N} \\
88^{\circ} 35.13 \mathrm{~W}\end{array}$ & Pseudophilothrips sp. nr. perseae \\
\hline Xoxocotlan & Oaxaca & 1504 & $\begin{array}{l}17^{\circ} 01.21 \mathrm{~N} \\
96^{\circ} 39.93 \mathrm{~W}\end{array}$ & $\begin{array}{l}\text { Frankliniella cephalica } \\
\text { Frankliniella cubensis } \\
\text { Frankliniella } \text { sp. nr. cubensis } \\
\text { Neohydatothrips burungae }\end{array}$ \\
\hline
\end{tabular}

Magellan, San Dimas California) derived coordinates and elevation for trees or orchards that yielded samples. Adult and larval thrips, mites, and micro-parasitoids were slide mounted in Hoyers and identified to species where possible. Keys used for thrips identifications were Mound and Marullo (1996), Sakimura and O'Neil (1979), and Wilson (1975).

\subsection{Host plant surveys in California, USA}

Potential host plants including avocados were sampled (May-June 1999) in three heavily infested California avocado orchards to determine if $S$. perseae was utilizing these plants for development. Plants sampled for $S$. perseae were: apple (Malus sp.), avocado ( $P$. americana), banana (Musa acuminata Colla), blackberry (Rubus sp.), blueberry (Vaccinium corymbosum L.), blue elderberry (Sambucus caerulea Raf.), Buddha's hand, key lime, mandarin, and tangelo (all Citrus spp.), cheeseweed (Malva sp.), cherimoya (Annona cherimola Mill.), coffee (Coffea sp.), eucalyptus (Eucalyptus spp.), grape (Vitis sp.), feijoa (Acca sellowiana [O. Berg.] Burrett), fig (Ficus carica L.), guava (Psidium sp.), lambsquarters (Chenopodium album L.), loquat (Eriobotrya japonica Thunb.), macadamia (Macadamia sp.), mango (Mangifera indica L.), oleander (Nerium oleander L.), olive (Olea europaea L.), papaya (Carica papaya L.), passion fruit (Passiflora edulis Sims), peach (Prunus persica (L.) Batsch), Persea indica (L.) K. Spreng, pomegranate (Punica granatum L.), sow thistle (Sonchus sp.), squash (Cucurbita spp.), stinging nettle (Urtica dioica L.), tamarillo (Cyphomandra betacea [Cav.] Sendtn.) tomato (Lycopersicon lycopersicum [L.] Karsten ex. Farwell), and wild tobacco (Nicotiana glauca Graham). 


\subsection{Foreign exploration for $S$. perseae and associated natural enemies}

In chronological order, foreign exploration for $S$. perseae was conducted in Mexico, Guatemala, Costa Rica, Dominican Republic, Trinidad, and Brazil. Only avocados were beat tray sampled for $S$. perseae and potential natural enemies.

Mexico. Avocados were sampled in Atlixco (state of Puebla, 11-12 October 1997), Coatepec-Harinas (state of Mexico, 10 October 1997), Ayutla, Chilapa de Diaz, San Francisco la Chigolio, San Andres Huayapan, Tlalixtac, Oaxaca, and Xoxocotlan (state of Oaxaca, 12-16 April 1998), Uruapan (state of Michoacan, 1812 October 1999), Piste and Valladolid (state of $\mathrm{Yu}-$ catan, 26-28 October 2000), and Coba, Tulum, and Muyil, (state of Quintana Roo, 28 October-3 November 2000).

Guatemala. Avocados were sampled in Sacatepequez, Antigua, and Altas (state of Guatemala, 26-29 October 1998) and Tal Petate (state of Santa Rosa 30 October, 1998).

Costa Rica. Avocados were sampled in Alajuela, Zarcero (state of Alajuela), Heredia (state of Heredia), and San Marcos de Tarrazu (state of San José). Sampling was conducted over 27-29 October 1999.

Dominican Republic. Avocados were sampled in El Cujuilito, San Cristobal, Bani, San José de Ocoa, Piedra Blanca, Bonao, and Rio San Juan (18-22 April 2000).

Trinidad. Avocados were sampled in Tunapuna (district of Tacarigua, 25 April 2000), St. Ann's (district of St. Ann's, 25 April 2000), Arima (district of Arima, 25 April 2000), Valencia (district of Valencia, 26 April 200), Sangre Grande and Manzanilla (district of Manzanilla, 26 April 2000), St. Joseph (district of Guayaguayare, 26 April 2000), Rio Claro (district of Cocal, 26 April 2000), Poole (district of Charuma, 26 April 2000), and Princes Town (district of Savana Grande, 26 April 2000).

Brazil. Avocados were sampled in Piracicaba, Araraquara, and Jaboticaba (state of São Paulo, 28-30 August 2000).

\section{Results}

\subsection{Host plant surveys for $S$. perseae in California, USA}

Of the 32 species of plants surveyed for S. perseae, adult thrips were detected on $34 \%$ of species examined, indicating that adult $S$. perseae adults are vagile and will land in detectable numbers on a variety of non-avocado host plants when pest densities in avocado orchards are high (Table 1). Larval $S$. perseae were only detected on avocados, suggesting that this insect may have a highly restricted host range in California (Table 1). Detection of Pseudanaphothrips achaetus (Bagnall) (Thysanoptera: Thripidae), from flowering weeds in a Bonsall (California) avocado orchard, was a new USA record for this species, which was previously known only from Australia and New Zealand (Table 1).

\subsection{Scirtothrips perseae survey results from Mexico, Central and South America, and the Caribbean}

Mexico. S. perseae was found on avocados in all locations that were sampled except for the Yucatan Peninsula (Table 2). Of the 801 slide mounted specimens identified from Mexico, $42 \%$ were S. perseae and 35\% were Neohydatothrips burungae Hood (Thysanoptera: Thripidae) (Fig. 1A). Few natural enemies associated with thrips on avocados were detected with the beat tray sampling method $(n=46)$. The most common natural enemy found with $S$. perseae was a predatory thrips,

A

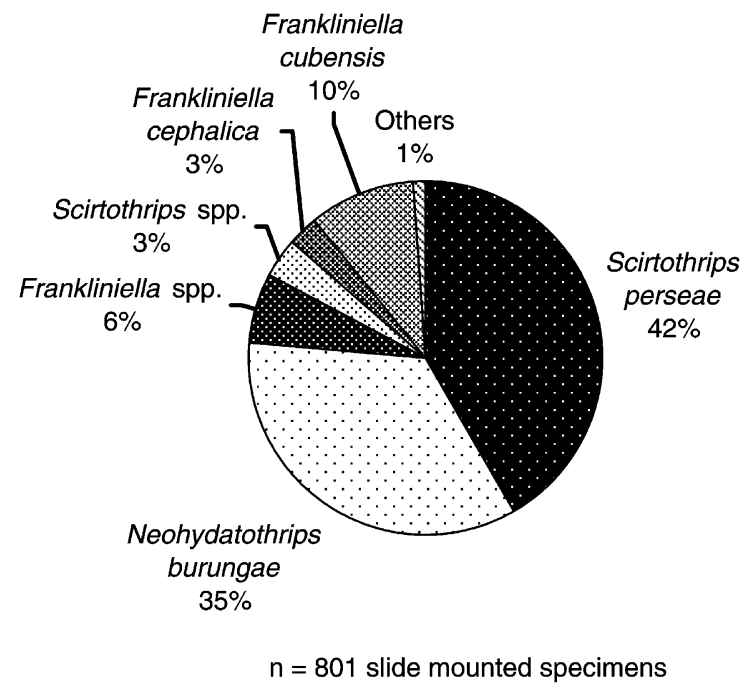

B

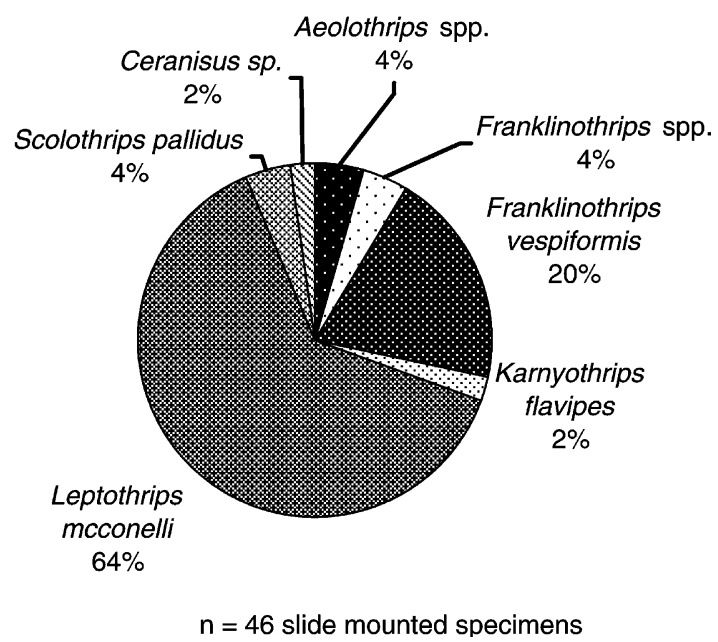

Fig. 1. Percentage composition of phytophagous thrips (A) and natural enemies (B) collected from avocados in Mexico. 
Leptothrips mcconnelli Crawford (Thysanoptera: Phlaeothripidae), (Fig. 1B) and it was only recovered from sites sampled in Oaxaca (Table 1). A single larval thrips endoparasitoid, an undescribed male Ceranisus (Hymenoptera: Eulophidae), was found in Chilapa de Diaz in the state of Oaxaca (Fig. 1B).

Guatemala. S. perseae was recovered at all sites sampled, except for the lowland coastal area of Tal Pete (state of Santa Rosa) (Table 3), and was the dominant thrips species recovered from avocados in Guatemala (Fig. 2A). Beat tray sampling recovered few thrips natural enemies $(n=12)$, and predatory Aeolothrips spp. (Thysanoptera: Aeolothripidae) dominated $(n=6)$ the natural enemy fauna (Fig. 2B). Two male Ceranisus sp. were found in Sorsoya in the state of Guatemala (Fig. 1B). Four adult predatory mites in the genus Balaustium (Acari: Erythraeidae) were recovered from Milpas Altas (state of Guatemala) (Fig. 1B).

Costa Rica. Avocados sampled in the states of Alajuela, San Josè, and Heredia in October 1999 did not result in collection of $S$. perseae. An undescribed congener, Scirtothrips n. sp., constituted $58 \%$ of collected specimens and dominated the thrips fauna (Fig. 3) in
$75 \%$ of sampled sites (Table 4 ). No thrips natural enemies were found during surveys.

Dominican Republic. No specimens of Scirtothrips were found on avocados in the Dominican Republic (Table 5). Frankliniella spp., in particular Frankliniella cubensis Hood (Thysanoptera: Thripidae), were the dominant thrips species recovered (Fig. 4A). Franklinothrips vespiformis Crawford (Aeolothripidae) was the dominant predator found along with Ceranisus sp. collected in San Josè de Ocoa (Fig. 4B).

Trinidad. No specimens of Scirtothrips were found on avocados in Trinidad (Table 6). Frankliniella spp., in particular the undescribed Frankliniella sp. 1, were the dominant thrips species recovered (Fig. 5A). Dolichothrips indicus Hood (Phalaeothripidae), an invasive thrips from India was collected at five sites (Table 6). Three species of predatory Phaleothripine thrips were recovered (Fig. 4B). Aleurodothrips fasciapennis (Franklin) is a whitefly and scale predator, and Karnyothrips spp. are assumed to be predatory, but the biology of this genus is poorly understood (Mound and Marullo, 1996). Two specimens of a Ceranisus sp. were collected in Tunapuna (Fig. 5B).

Table 3

Phytophagous and predatory thrips found on avocados in Guatemala

\begin{tabular}{|c|c|c|c|c|}
\hline Town or city & State & Elevation (m) & GPS coordinates & Thrips species found \\
\hline Antigua & Guatemala & 2103 & $\begin{array}{l}14^{\circ} 34.67 \mathrm{~N} \\
90^{\circ} 37.85 \mathrm{~W}\end{array}$ & $\begin{array}{l}\text { Pseudophilothrips perseae } \\
\text { Neohydatothrips sp. } \\
\text { Scirtothrips perseae }\end{array}$ \\
\hline Chylla & Guatemala & 2136 & $\begin{array}{l}14^{\circ} 37.95 \mathrm{~N} \\
90^{\circ} 41.51 \mathrm{~W}\end{array}$ & $\begin{array}{l}\text { Frankliniella williamsi Hood } \\
\text { Frankliniella } \mathrm{sp} . \\
\text { Neohydatothrips } \mathrm{sp} . \\
\text { Pseudophilothrips perseae } \\
\text { Scirtothrips aceri } \\
\text { Scirtothrips perseae }\end{array}$ \\
\hline Milpas Altas & Guatemala & 2317 & $\begin{array}{l}14^{\circ} 35.64 \mathrm{~N} \\
90^{\circ} 39.98 \mathrm{~W}\end{array}$ & $\begin{array}{l}\text { Aeolothrips sp. } \\
\text { Frankliniella } \mathrm{sp} . \mathrm{nr} \text {. bruneri } \\
\text { Frankliniella cubensis } \\
\text { Frankliniella gardeniae Moulton } \\
\text { Scirtothrips perseae } \\
\text { Scirtothrips } \mathrm{sp} \text {. }\end{array}$ \\
\hline Sorsoya & Guatemala & 2051 & $\begin{array}{l}14^{\circ} 35.01 \mathrm{~N} \\
90^{\circ} 39.01 \mathrm{~W}\end{array}$ & $\begin{array}{l}\text { Aeolothrips mexicanus } \\
\text { Aeolothrips sp. nr. mexicanus } \\
\text { Aeolothrips vittipennis Hood } \\
\text { Bravothrips kraussi (Crawford) } \\
\text { Bravothrips sp. nr. kraussi } \\
\text { Dinurothrips vezenyii (Bagnall) } \\
\text { Frankliniella cubensis } \\
\text { Frankliniella gossypiana } \\
\text { Frankliniella williamsi } \\
\text { Frankliniella sp. minuta Moulton group } \\
\text { Neohydatothrips burungae } \\
\text { Scirtothrips aceri } \\
\text { Scirtothrips perseae } \\
\text { Selenothrips rubrocinctus (Giard) }\end{array}$ \\
\hline Tal Petate & Santa Rosa & 21 & $\begin{array}{l}14^{\circ} 00.14 \mathrm{~N} \\
90^{\circ} 27.95 \mathrm{~W}\end{array}$ & $\begin{array}{l}\text { Frankliniella gardeniae } \\
\text { Karnyothrips merrilli (Watson) }\end{array}$ \\
\hline
\end{tabular}


A

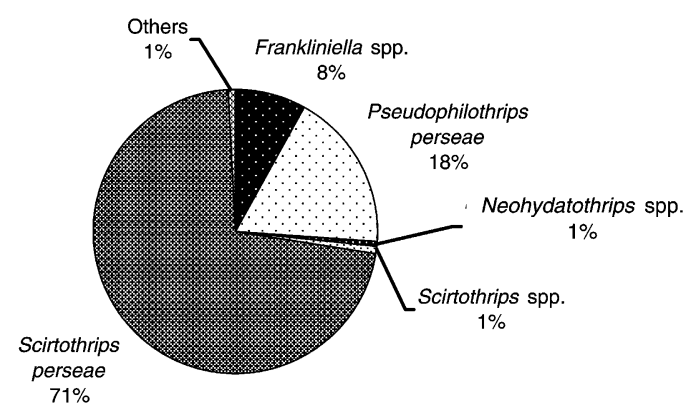

$\mathrm{n}=575$ slide mounted specimens

B

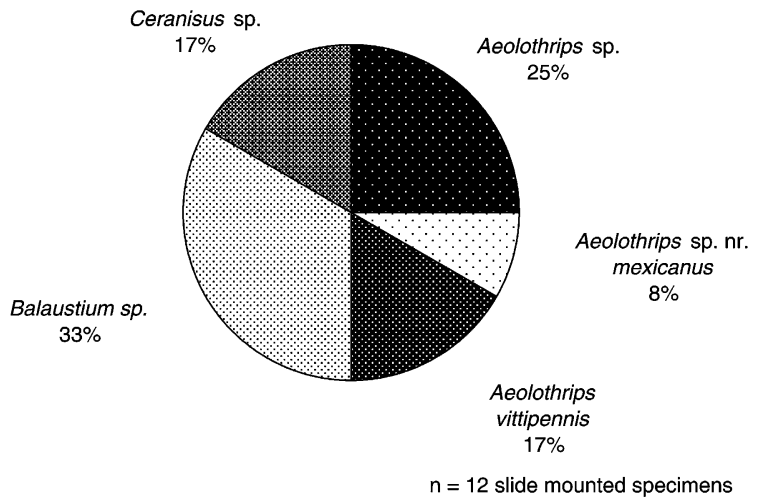

Fig. 2. Percentage composition of phytophagous thrips (A) and natural enemies (B) collected from avocados in Guatemala.

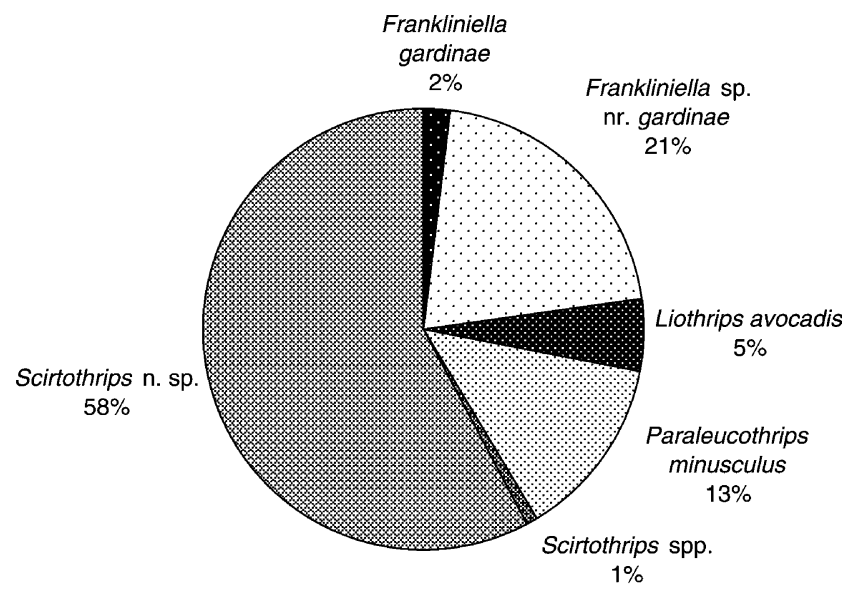

$\mathrm{n}=246$ slide mounted specimens

Fig. 3. Percentage composition of phytophagous thrips collected from avocados in Costa Rica.

Brazil. No specimens of Scirtothrips were collected from avocados in São Paulo, Brazil (Table 7). Two undescribed species of Frankliniella (Frankliniella sp. 5 and Frankliniella sp. 6) dominated the collected thrips fauna (Fig. 6). No natural enemy species were found during surveys.

\section{Discussion}

Exploration for $S$. perseae in Mexico, Central and South America, and the Caribbean delineated a home range for this pest that extends from high altitude areas $(>1500 \mathrm{~m}$ above sea level) in central (Michoacan, Coatepec-Harinas, and Atlixco) and southern (Oaxaca) Mexico to similar high elevation areas around Guatemala City and Antigua in Guatemala. In Costa Rica, $S$. perseae was replaced as the dominant phytophagous thrips on avocados by an undescribed congener on avocados grown at high altitudes $(>1300 \mathrm{~m}$ above sea level). Scirtothrips perseae was not found on avocados grown in lowland areas of Mexico (i.e., the Yucatan Peninsula) and Guatemala (i.e., Tel Petate) (both areas $<30 \mathrm{~m}$ above sea level) (Fig. 7). In the Caribbean, no members of the genus Scirtothrips were found on avocados, and in South America, avocado sampling yielded negative results for this genus in Brazil (this study) and Chile (L.A. Mound, personal communication 2001). S. perseae is found in California avocado orchards at elevations $<300 \mathrm{~m}$ where cool sea breezes moderate summer temperatures. S. perseae persists at very low noneconomic densities in hotter interior orchards where cool marine breezes do not reach (Hoddle, 2002a). The marine influence in coastal California avocado orchards may produce yearly temperature regimens similar to those under which $S$. perseae evolved at high altitudes in Mexico and Guatemala thereby facilitating the establishment of this pre-adapted pest in California.

The natural enemy fauna associated with $S$. perseae and other phytophagous thrips on avocados in nearly all areas surveyed was not abundant and comprised just $4.26 \%$ of collected material. A total of 95 natural enemies from six genera with known predatory thrips (Aeolothrips, Aleurodothrips [whitefly and scale specialists], Franklinothrips, Leptothrips, Scolothrips [mite specialists], and Karnyothrips), one genus of hymenopterous parasitoid (Ceranisus) and a predatory mite (Balaustium) were found. Ceranisus sp. adults $(n=7)$ were most abundant in the Dominican Republic in association with relatively large numbers of $F$. vespiformis $(n=24)$, which were feeding on immature Pseudacysta perseae (Heidemann) (Hemiptera: Tingidae). This parasitoid may have been using larval $F$. vespiformis as hosts, although neither this thrips nor any other member of the Aeolothripidae are known hosts for Ceranisus (Loomans et al., 1997).

The prospects for importation of an effective thrips natural enemy associated with $S$. perseae for use in a classical biological control program in California are not 
Table 4

Phytophagous thrips found on avocados in Costa Rica

\begin{tabular}{|c|c|c|c|c|}
\hline Town or city & State & Elevation $(\mathrm{m})$ & GPS coordinates & Thrips species found \\
\hline Carrizal & Alajuela & 1558 & $\begin{array}{l}10^{\circ} 06.04 \mathrm{~N} \\
84^{\circ} 09.75 \mathrm{~W}\end{array}$ & $\begin{array}{l}\text { Scirtothrips aceri } \\
\text { Scirtothrips } \mathrm{n} . \mathrm{sp} . \\
\text { Paraleucothrips minusculus Johansen } \\
\text { Frankliniella gardeniae } \\
\text { Liothrips avocadis } \text { Hood }\end{array}$ \\
\hline San Marcos de Tarrazú & San Josè & 1717 & $\begin{array}{l}09^{\circ} 40.22 \mathrm{~N} \\
83^{\circ} 59.63 \mathrm{~W}\end{array}$ & $\begin{array}{l}\text { Frankliniella } \mathrm{sp} . \mathrm{nr} \text {. gardeniae } \\
\text { Liothrips avocadis } \\
\text { Scirtothrips lumarius Mound \& Marullo }\end{array}$ \\
\hline Santa Barbara & Heredia & 1316 & $\begin{array}{l}10^{\circ} 03.48 \mathrm{~N} \\
84^{\circ} 08.29 \mathrm{~W}\end{array}$ & $\begin{array}{l}\text { Liothrips avocadis } \\
\text { Paraleucothrips minusculus } \\
\text { Scirtothrips n. sp. }\end{array}$ \\
\hline Zacero & Alajuela & 1548 & $\begin{array}{l}10^{\circ} 10.16 \mathrm{~N} \\
84^{\circ} 22.90 \mathrm{~W}\end{array}$ & Scirtothrips n. sp \\
\hline
\end{tabular}

Table 5

Phytophagous and predatory thrips found on avocados in the Dominican Republic

\begin{tabular}{|c|c|c|c|c|}
\hline Town or city & State & Elevation (m) & GPS coordinates & Thrips species found \\
\hline Bani & - & 30 & $\begin{array}{l}18^{\circ} 15.90 \mathrm{~N} \\
70^{\circ} 20.65 \mathrm{~W}\end{array}$ & $\begin{array}{l}\text { Chaetanaphothrips leeuweni (Karny) } \\
\text { Frankliniella cubensis } \\
\text { Franklinothrips vespiformis }\end{array}$ \\
\hline Banoa & - & 251 & $\begin{array}{l}18^{\circ} 58.64 \mathrm{~N} \\
70^{\circ} 25.58 \mathrm{~W}\end{array}$ & $\begin{array}{l}\text { Franklinothrips vespiformis } \\
\text { Selenothrips rubrocinctus } \\
\text { Leucothrips piercei (Morgan) }\end{array}$ \\
\hline El Cujuilito & - & 61 & $\begin{array}{l}18^{\circ} 15.65 \mathrm{~N} \\
70^{\circ} 22.69 \mathrm{~W}\end{array}$ & $\begin{array}{l}\text { Frankliniella cubensis } \\
\text { Franklinothrips vespiformis }\end{array}$ \\
\hline San Cristobal & - & 131 & $\begin{array}{l}18^{\circ} 25.91 \mathrm{~N} \\
70^{\circ} 03.05 \mathrm{~W}\end{array}$ & $\begin{array}{l}\text { Frankliniella bruneri } \\
\text { Frankliniella cubensis } \\
\text { Franklinothrips vespiformis }\end{array}$ \\
\hline San Josè de Ocoa & - & 693 & $\begin{array}{l}18^{\circ} 41.54 \mathrm{~N} \\
70^{\circ} 26.72 \mathrm{~W}\end{array}$ & $\begin{array}{l}\text { Frankliniella bruneri } \\
\text { Frankliniella cubensis } \\
\text { Frankliniella insularis } \\
\text { Franklinothrips vespiformis } \\
\text { Haplothrips gowdeyi } \\
\text { Heliothrips haemorrhoidalis } \\
\text { Selenothrips rubrocinctus }\end{array}$ \\
\hline
\end{tabular}

encouraging as attested by the low populations of natural enemies and limited diversity of species relative to the abundance of this pest in Mexico and Guatemala. However, two caveats that should be noted are related to the sampling protocol employed and the time of year samples were taken. First, beat tray sampling may not be an effective method for sampling thrips natural enemies. Winged predatory hemipterans and parasitic Hymenoptera may have flown away without detection during the beat tray sampling process while less vagile species were captured. Second, the phenology of $S$. perseae in its home range is unstudied. In California, S. perseae population densities vary significantly throughout the year as does the generalist natural enemy fauna responding to population outbreaks (Hoddle, 2002a). Consequently, time of year that foreign exploration was conducted for $S$. perseae could have a significant impact on natural enemy species detected and their relative abundance. Manipulative field studies have revealed that native thrips species can be regulated by indigenous generalist natural enemies that respond in a density-dependent manner to population outbreaks (Funderburk et al., 2000). Therefore a multi-year study of $S$. perseae and associated natural enemies on avocados in the pest's home range will be necessary to fully understand its population dynamics, to identify the full suite of biological control agents, and to determine the efficacy of the natural enemy guild associated with $S$. perseae.

There are no well-documented "classical" biological control programs where an imported natural enemy 


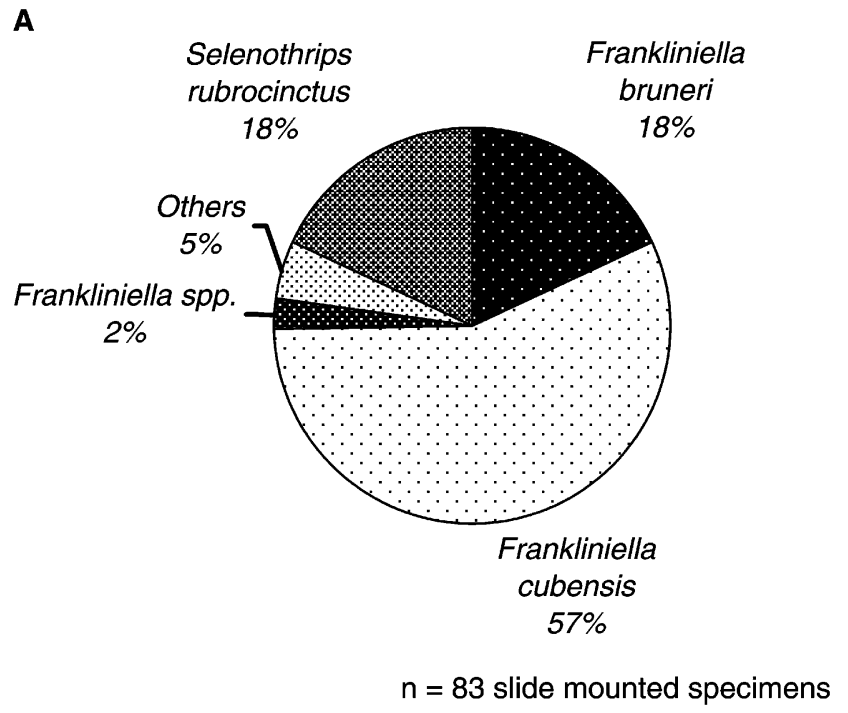

B

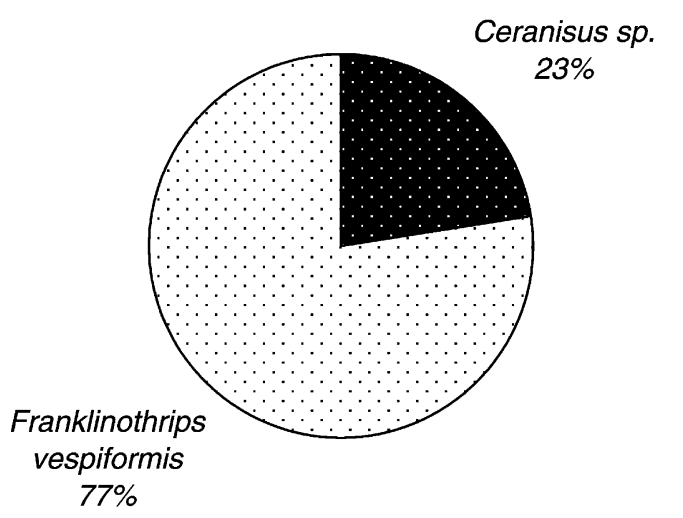

$\mathrm{n}=31$ slide mounted specimens

Fig. 4. Percentage composition of phytophagous thrips (A) and natural enemies (B) collected from avocados in the Dominican Republic.

has been effective against an exotic thrips pest. Thripobius semiluteus Boucek (Hymenoptera: Eulophidae) was imported into California from Australia and Brazil during 1986-1988 to control Heliothrips haemorrhoidalis (Bouchè), a serious pest of avocado fruit. This parasitoid has been established in California and reportedly provided control of $H$. haemorrhoidalis (McMurtry et al., 1991). However, there have been no rigorous evaluation and quantification of the impact of $T$. semiluteus on $H$. haemorrhoidalis in California (e.g., life table studies) and successful suppression of this pest may have occurred through the adoption of new fruit harvesting strategies (Phillips, 1997) or the use of new insecticides like abamectin and spinosad that have been registered for use in California against $S$. perseae. Thripobius semiluteus was recently released in New Zealand for biological control of $H$. haemorrhoidalis in avocados (P. Stevens, personal communication 2001).
Apart from locating natural enemies and delineating the geographic distribution of $S$. perseae, foreign exploration allowed the compilation of a list of other phytophagous thrips species unknown in California which could be serious avocado pests should they become established. One species, Neohydatothrips burungae, was as common as $S$. perseae on avocados in Mexico and is not known to be present in California. Given the common occurrence of $S$. perseae on avocados in Mexico and its pestiferous nature in California, $N$. burungae could also pose a threat to California grown avocados.

The threat of new avocado pests of exotic origin establishing in California has increased substantially with the recent legalization of avocado imports from Mexico into the USA, a trade practice that had been banned since 1914 to prevent the unwanted introduction of arthropods, especially Anastrepha sp. (Diptera: Tephritidae) that infest fruit (Morse et al., 1995).

The three most recent avocado pests to establish in California are Tetraleurodes perseae Nakahara (Homoptera: Aleyrodidae), Oligonychus perseae Tuttle, Baker, and Abbatiello (Acari: Tetranychidae), and $S$. perseae and were found in 1982, 1990, and 1996, respectively. Tetraleurodes perseae and $S$. perseae were new to science at the time of their initial discovery in California (Nakahara, 1995, 1997; Rose and Woolley, 1984). Oligonychus perseae was first described from specimens intercepted at a border inspection station in El Paso, Texas, USA (Tuttle et al., 1976) and both $T$. perseae and $S$. perseae had been previously intercepted at border ports of entry before detection in California. These facts highlight three important points.

First, there are probably additional serious avocado pests in Central America that are unknown entities that may be able to establish in California and inflict severe damage to commercially grown avocados. Foreign exploration for $S$. perseae and its natural enemies has revealed at least four new species of Frankliniella from Costa Rica, the Caribbean, and South America. In addition, there is at least one new species of Scirtothrips from Costa Rica, which dominates the thrips fauna on avocados in that country. Furthermore, only three species of thrips (Frankliniella cephalica [Crawford], Heliothrips haemorrhoidalis [already present in California], and Pseudophilothrips perseae [Watson]) from Mexico are listed as potential pests by USDA-APHIS (Firko, 1995). All three species have been collected during the exploration efforts reported here. However, from examination of 2136 slide mounted specimens in this study, over 47 species of phytophagous thrips in at least 19 genera have been recorded from avocados in areas outside of California. Of collected specimens, it is unknown how many species were collected as incidental visitors that originated from other host plants. A total of 38 phytophagous thrips species have been collected from 
Table 6

Phytophagous and predatory thrips found on avocados in Trinidad

\begin{tabular}{|c|c|c|c|c|}
\hline Town or city & District & Elevation $(\mathrm{m})$ & GPS coordinates & Thrips species found \\
\hline Arima & Arima & 74 & $\begin{array}{l}10^{\circ} 38.69 \mathrm{~N} \\
61^{\circ} 17.35 \mathrm{~W}\end{array}$ & Dolichothrips indicus (Hood) \\
\hline Arouca & Tacarigua & 73 & $\begin{array}{l}10^{\circ} 37.98 \mathrm{~N} \\
61^{\circ} 19.60 \mathrm{~W}\end{array}$ & $\begin{array}{l}\text { Dolichothrips indicus } \\
\text { Frankliniella insularis }\end{array}$ \\
\hline Barataria & St. Ann's & 52 & $\begin{array}{l}10^{\circ} 38.80 \mathrm{~N} \\
61^{\circ} 21.67 \mathrm{~W}\end{array}$ & $\begin{array}{l}\text { Dolichothrips indicus } \\
\text { Frankliniella } \text { sp. } 1 \\
\text { Frankliniella } \text { sp. } 2^{*} \\
\text { Frankliniella } \text { sp. } 3 \\
\text { Frankliniella insularis } \\
\text { Frankliniella parvula Hood } \\
\text { Rhamphothrips pandens Sakimura } \\
\text { Selenothrips rubrocinctus }\end{array}$ \\
\hline Manzanilla & Manzanilla & 29 & $\begin{array}{l}10^{\circ} 30.90 \mathrm{~N} \\
61^{\circ} 02.85 \mathrm{~W}\end{array}$ & $\begin{array}{l}\text { Frankliniella } \text { sp. } 1 \\
\text { Frankliniella insularis } \\
\text { Frankliniella } \text { sp. nr. kelliae Sakimura } \\
\text { Frankliniella parvula Hood }\end{array}$ \\
\hline Maraval & Diego Martin & 96 & $\begin{array}{l}10^{\circ} 39.99 \mathrm{~N} \\
61^{\circ} 29.60 \mathrm{~W}\end{array}$ & $\begin{array}{l}\text { Frankliniella } \text { sp. } 1 \\
\text { Neohydatothrips geminus (Hood) } \\
\text { Rhamphothrips pandens }\end{array}$ \\
\hline Maturita & Arima & 116 & $\begin{array}{l}10^{\circ} 38.52 \mathrm{~N} \\
61^{\circ} 16.29 \mathrm{~W}\end{array}$ & $\begin{array}{l}\text { Dolichothrips indicus } \\
\text { Frankliniella } \text { sp. } 1\end{array}$ \\
\hline Poole & Charuma & 77 & $\begin{array}{l}10^{\circ} 17.94 \mathrm{~N} \\
61^{\circ} 13.45 \mathrm{~W}\end{array}$ & $\begin{array}{l}\text { Frankliniella sp. } 1 \\
\text { Selenothrips rubrocinctus }\end{array}$ \\
\hline Princes Town & Savana Grande & 60 & $\begin{array}{l}10^{\circ} 16.17 \mathrm{~N} \\
61^{\circ} 22.71 \mathrm{~W}\end{array}$ & $\begin{array}{l}\text { Frankliniella } \text { sp. } 1 \\
\text { Frankliniella } \text { sp. nr. kelliae } \\
\text { Frankliniella parvula } \\
\text { Karnyothrips merrilli }\end{array}$ \\
\hline Rio Claro & Cocal & 72 & $\begin{array}{l}10^{\circ} 18.38 \mathrm{~N} \\
61^{\circ} 10.05 \mathrm{~W}\end{array}$ & $\begin{array}{l}\text { Frankliniella } \text { sp. } 1 \\
\text { Karnyothrips longiceps Hood }\end{array}$ \\
\hline Sangre Grande & Manzanilla & 59 & $\begin{array}{l}10^{\circ} 35.18 \mathrm{~N} \\
61^{\circ} 07.62 \mathrm{~W}\end{array}$ & $\begin{array}{l}\text { Frankliniella } \text { sp. } 1 \\
\text { Frankliniella insularis } \\
\text { Frankliniella } \text { sp. nr. kelliae } \\
\text { Frankliniella parvula } \\
\text { Microcephalothrips abdominalis (Crawford) }\end{array}$ \\
\hline St. Joseph & Guayaguayare & 9 & $\begin{array}{l}10^{\circ} 18.44 \mathrm{~N} \\
61^{\circ} 00.14 \mathrm{~W}\end{array}$ & $\begin{array}{l}\text { Frankliniella } \text { sp. } 1 \\
\text { Heliothrips haemorrhoidalis }\end{array}$ \\
\hline Tunapuna & Tacarigua & 159 & $\begin{array}{l}10^{\circ} 39.56 \mathrm{~N} \\
61^{\circ} 23.57 \mathrm{~W}\end{array}$ & $\begin{array}{l}\text { Anisopilothrips venustulus (Priesner) } \\
\text { Dolichothrips indicus } \\
\text { Frankliniella } \text { sp. } 1 \\
\text { Frankliniella insularis } \\
\text { Frankliniella } \text { sp. nr. kelliae } \\
\text { Heliothrips haemorrhoidalis } \\
\text { Neohydatothrips geminus (Hood) } \\
\text { Rhamphothrips pandens }\end{array}$ \\
\hline Valencia & Valencia & 81 & $\begin{array}{l}10^{\circ} 38.87 \mathrm{~N} \\
61^{\circ} 12.50 \mathrm{~W}\end{array}$ & $\begin{array}{l}\text { Aleurodothrips fasciapennis (Franklin) } \\
\text { Frankliniella sp. } 1 \\
\text { Frankliniella insularis } \\
\text { Frankliniella parvula } \\
\text { Heliothrips haemorrhoidalis }\end{array}$ \\
\hline
\end{tabular}

\footnotetext{
${ }^{*}$ New species near cephalica.
}

avocados in Mexico by Johansen et al. (1999), but only seven species, Frankliniella bruneri Priesner, F. chamulae Johansen, Heliothrips haemorrhoidalis, Pseudophilothr- ips perseae, Scirtothrips aguacatae Johansen and MojicaGuzmán, Scirtothrips kupandae Johansen and MojicaGuzmán, and $S$. perseae were considered pests 


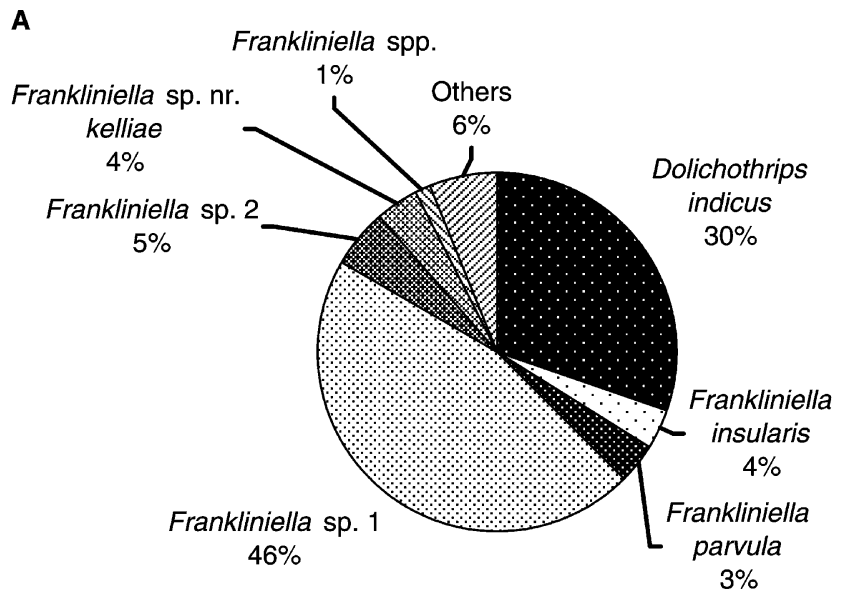

$\mathrm{n}=347$ slide mounted specimens

B

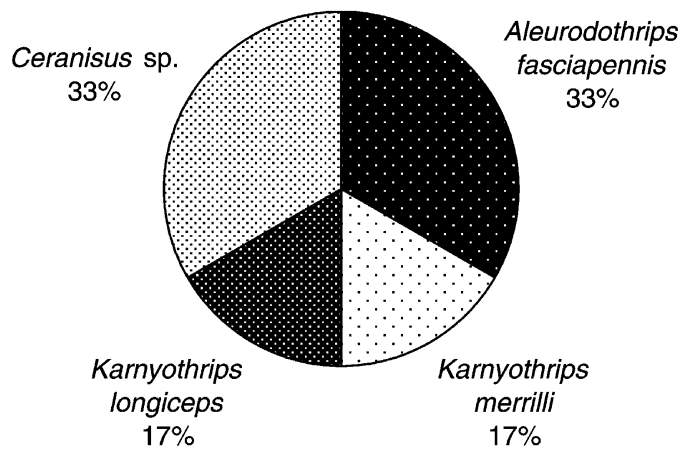

$\mathrm{n}=6$ slide mounted specimens

Fig. 5. Percentage composition of phytophagous thrips (A) and natural enemies (B) collected from avocados in Trinidad.
(Hernández et al., 2000). The validity of new Scirtothrips species collected from avocados in Mexico and described in a recent taxonomic review (Johansen and Mojica-Guzmán, 1998) has been questioned as species designations were made according to morphological characters that exhibit high variation amongst individuals of the same species (Mound and zur Strassen, 2001).

Broad spectrum pesticide use in commercial Mexican avocado orchards for suppression of serious pests (e.g., tephritids [Anastrepha spp.] and curculionids [Heilipus and Conotrachelus spp.]) may inadvertently control thrips that would be problematic in the absence of sprays. This scenario most likely explains the relatively unimportant status of $S$. perseae as a pest in commercial Mexican orchards, while in non-commercial, unsprayed orchards $S$. perseae densities reach levels that cause leaf and fruit damage similar to that in California (MSH, personal observations in Coatepec-Harinas). Consequently, deficits in knowledge on the taxonomy, ecology, and biology of the arthropod fauna on commercially grown avocados in exporting countries may render any mitigation of accidental pest importation practices ineffectual.

Second, APHIS-PPQ at Mexican border ports of entry intercepted both $O$. perseae (Tuttle et al., 1976) and $S$. perseae on avocados from Mexico before either pest became established in California. This strongly suggests that interception and exclusion policies are extremely valuable in preventing exotic avocado pests from Central America entering and establishing in California. The biology of potentially serious pests, like thrips for example, makes detection very difficult. Thrips eggs are extremely small and are usually laid within the tissue of leaves or skin of fruit. The numbers of eggs laid within individual leaves and fruit in orchards infested

Table 7

Phytophagous thrips found on avocados in Brazil

\begin{tabular}{|c|c|c|c|c|}
\hline Town or city & State & Elevation $(\mathrm{m})$ & GPS coordinates & Thrips species found \\
\hline Ararraquara & São Paulo & 634 & $\begin{array}{l}22^{\circ} 42.27 \mathrm{~S} \\
47^{\circ} 37.17 \mathrm{~W}\end{array}$ & $\begin{array}{l}\text { Frankliniella } \text { sp. } 5 \\
\text { Frankliniella } \mathrm{sp} .6 \\
\text { Frankliniella condei John } \\
\text { Frankliniella rodeos Moulton } \\
\text { Frankliniella schultzei (Trybom) } \\
\text { Haplothrips gowdeyi }\end{array}$ \\
\hline Jaboticaba & São Paulo & 562 & $\begin{array}{l}21^{\circ} 16.59 \mathrm{~S} \\
48^{\circ} 17.58 \mathrm{~W}\end{array}$ & $\begin{array}{l}\text { Frankliniella } \text { sp. } 5 \\
\text { Frankliniella } \text { sp. } 6 \\
\text { Frankliniella condei } \\
\text { Haplothrips gowdeyi }\end{array}$ \\
\hline Piracicaba & São Paulo & 327 & $\begin{array}{l}22^{\circ} 42.27 \mathrm{~S} \\
47^{\circ} 37.17 \mathrm{~W}\end{array}$ & $\begin{array}{l}\text { Frankliniella } \text { sp. } 5 \\
\text { Frankliniella } \text { sp. } 6 \\
\text { Frankliniella condei } \\
\text { Frankliniella gemina Bagnall } \\
\text { Frankliniella rodeos } \\
\text { Heliothrips haemorrhoidalis }\end{array}$ \\
\hline
\end{tabular}




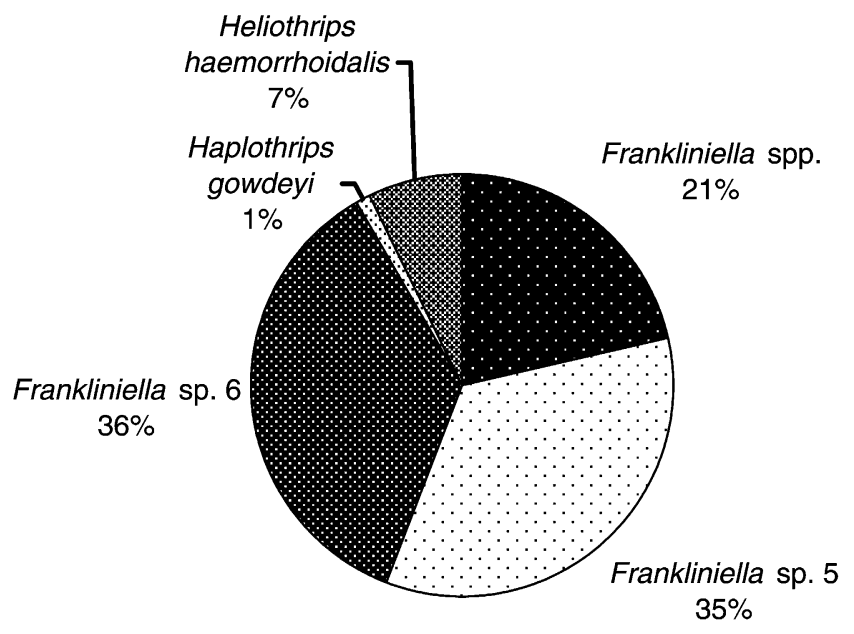

$\mathrm{n}=84$ slide mounted specimens

Fig. 6. Percentage composition of phytophagous thrips collected from avocados in Brazil.

with $S$. perseae in California can easily exceed 20 (Hoddle, 2002c). Plant material entering the USA (either legally or illegally) with this number of viable eggs provides a good-sized cohort that could establish a reproducing population in a permissive environment (i.e., abundant food, mild climate, lack of natural enemies).

Third, the small numbers of pests intercepted at border inspection stations on avocado plants that are moved into the USA suggest that founding populations of pests may often be very small. Work on Sericothrips staphylinus Haliday (Thysanoptera: Thripidae) used for the biological control of Ulex europaeus (L.), a noxious weed in New Zealand, has demonstrated that $33 \%$ of carefully managed releases of just 10 adult thrips into a permissive environment can result in establishment and proliferation (Memmott et al., 1998). The greater the frequency of small introductions, the higher the likelihood of establishment in comparison with fewer introductions of larger numbers of thrips which might go extinct due to adverse chance effects (Memmott et al., 1998). This scenario from biological control of weeds may apply to the establishment of new thrips pests outside of their home range, that is, frequent introductions of small numbers of pests may ultimately lead to establishment when founding populations encounter a permissive environment.

\section{Acknowledgments}

Financial support for this work came in part from the California Avocado Commission and the Beneficial Arthropod Exploration Fund Committee, College of Natural and Agricultural Sciences, University of California at Riverside. Serguei Triapitsyn, University of California Riverside, assisted with identification of $\mathrm{Ce}$ ranisus sp. and Ron Ochoa, Systematic Entomology Laboratory, ARS, USDA, Beltsville, Maryland identified the Balaustium sp. We are indebted for the assistance and cooperation of colleagues in Mexico (Refugio Lomeli Flores, Alejandro Perez Panduro, and workers at Fundacion Salvador Sanchez Colin in Coatepec-

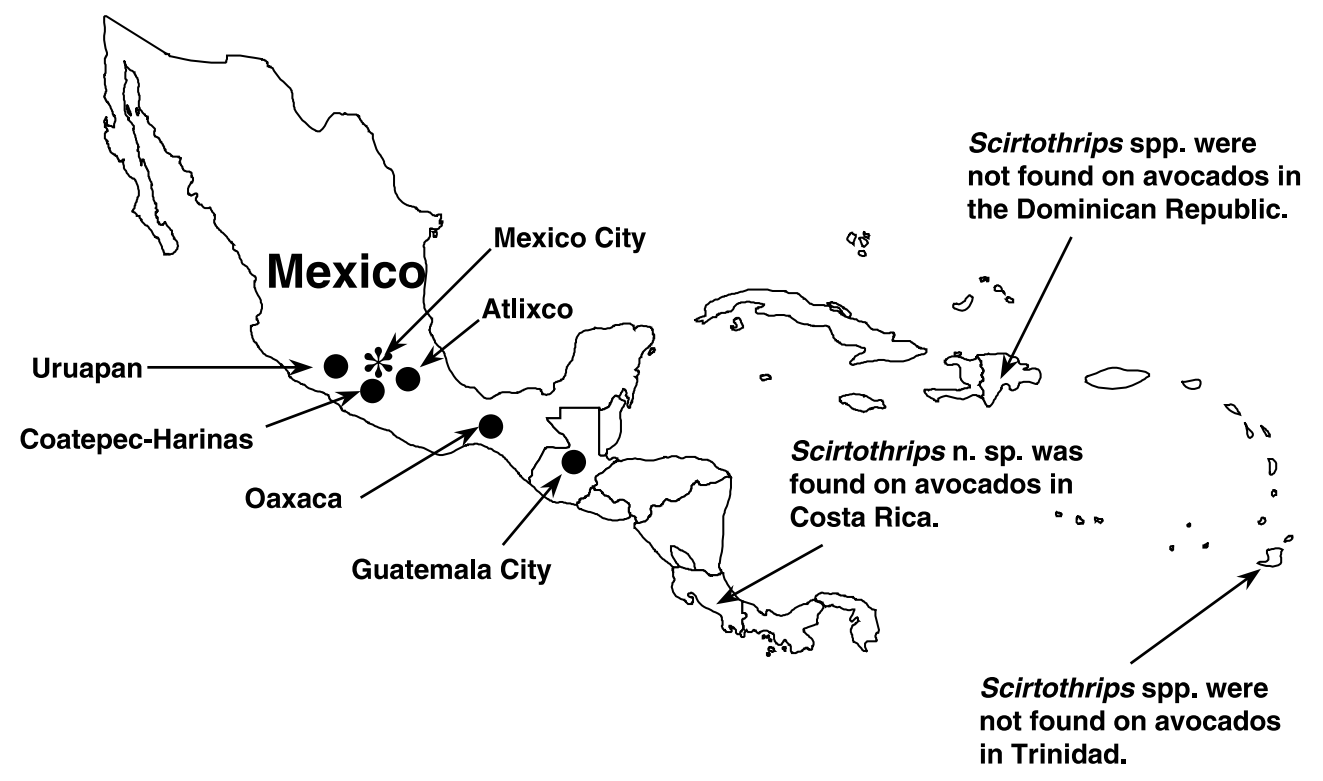

Locations where foreign exploration efforts found Scirtothrips perseae on avocados.

Fig. 7. Geographic distribution of Scirtothrips perseae in Mexico and Central America. 
Harinas), Guatemala (Wilmar Méndez Mérida of Profruta, Amilcar Casasola of BioAgroservices), Costa Rica (Paul Hansen, University of Costa Rica), the Dominican Republic (Alejandro Bencosme and Manuel Castillo, AgroForestry Macapai), Trinidad (Moses Kairo, CABI), and Brazil (Jào Lopes, University of Sáo Paulo).

\section{References}

Bellows Jr., T.S., Legner, E.F., 1993. Foreign exploration. In: Van Driesche, R.G.Bellows Jr., T.S. (Eds.), Steps in Classical Arthropod Biological Control. Proceedings of Thomas Say Publications in Entomology. Entomological Society of America, Lanham Maryland, pp. 25-42.

Firko, M.J., 1995. Importation of avocado fruit (Persea americana) from Mexico: Supplemental Risk Assessment. Available from: http://www.aphis.usda.gov/ppq/avocados/PRAmemo.pdf.

Fleschner, C.A., 1954. Biological control of avocado pests. California Avocado Society Yearbook 38, 125-129.

Fleschner, C.A., Hall, J.C., Ricker, D.W., 1955. Natural balance of mite pests in an avocado grove. California Avocado Society Yearbook 39, 155-162.

Funderburk, J., Stavisky, J., Olsen, S., 2000. Predation of Frankliniella occidentalis (Thysanoptera: Thripidae) in field peppers by Orius insidiosus (Hemiptera: Anthocoridae). Environmental Entomology 29, 376-382.

Hernández, H.G., Johansen, R.M., Corona, L.G., Martínez, Castro, A.S., Venegas, E.E., de Anda, F.D., Valle de la Paz, A.R., 2000. Plagas de aguacate. In: Téliz, D. (Ed.), El Aguacate y su Manejo Integrado. Ediciones Mundi-Prensa, México DF, pp. 117136.

Hoddle, M.S., Morse, J.G., 1997. Avocado thrips: a serious new pest of avocados in California. California Avocado Society Yearbook $81,81-90$.

Hoddle, M.S., Morse, J.G., 1998. Avocado thrips update. Citrograph $83,3-7$.

Hoddle, M.S., Morse, J.G., Phillips, P., Faber, B., 1998. Progress on management of avocado thrips. California Avocado Society Yearbook 82, 87-100.

Hoddle, M.S., Morse, J.G., Phillips, P., Faber, B., 1999. Avocado thrips update. Citrograph 84, 13-14.

Hoddle, M.S., 2002a. Phenology of Scirtothrips perseae Nakahara (Thysanoptera: Thripidae) and associated natural enemies in southern California avocado orchards. Environmental Entomology (submitted).

Hoddle, M.S., 2002b. Developmental and reproductive biology of Scirtothrips perseae Nakahara (Thysanoptera: Thripidae): a new avocado pest in California. Bulletin of Entomological Research (in press).

Hoddle, M.S., 2002c. Oviposition preferences of Scirtothrips perseae Nakahara (Thysanoptera: Thripidae) in southern California avocado orchards. Pan Pacific Entomologist, in press.

Jetter, K., 1999. Case Studies: citrus canker; avocado thrips and mites. In: Coppock, R.H., Kreith, M. (Eds.), Exotic Pests and Diseases: Biology, Economics, Public Policy. University of California Agricultural Issues Center, Davis, pp. 124-129.

Johansen, R.M., Mojica-Guzmán, A., 1998. The genus Scirtothrips Shull, 1909 (Thysanoptera: Thripidae, Sericothripini), in Mexico. Folia Entomologica (Mexico) 104, 23-108.

Johansen, R.M., Mojica-Guzmán, A., Ascención-Betanzos, G., 1999. Introducción a conocimiento de los insectos tisanópterous Mexicanos, en el agucatero (Persea americana Miller). Revista Chapingo Serie Horticultura 5, 279-295.
Kopp, L.E., 1966. A taxonomic revision of the genus Persea in the western hemisphere (Perseae-Lauraceae). Memoirs of the New York Botanical Garden 14, 1-120.

Lewis, T., 1973. Thrips, Their Biology, Ecology, and Economic Importance. Academic Press, London.

Loomans, A.J.M., Tamotsu, M., Greene, I.D., 1997. Interactions with hymenopterous parasitoids and parasitic nematodes. In: Lewis, T. (Ed.), Thrips as Crop Pests. CAB International, Wallingford, pp. 355-397.

McMurtry, J.A., 1992. The role of exotic natural enemies in the biological control of insect and mite pests of avocado in California. In: Proceedings of the 2nd World Avocado Congress, pp. 247252.

McMurtry, J.A., Johnson, H.G., Newberger, S.J., 1991. Imported parasite of greenhouse thrips established on California avocado. California Agriculture 45, 31-32.

Memmott, J., Fowler, S.V., Hill, R.L., 1998. The effect of release size on the probability of establishment of biological control agents: gorse thrips (Sericothrips staphylinus) released against gorse (Ulex europaeus) in New Zealand. Biocontrol Science and Technology 8 , $103-115$.

Mhameed, S., Sharon, D., Kaufman, D., Lahav, E., Hillel, J., Degani, C., Lavi, U., 1997. Genetic relationships within avocado (Persea americana Mill) cultivars and between Persea species. Theoretical and Applied Genetics 94, 279-286.

Morse, J.G., Metcalf, R.L., Arpaia, M.L., Rice, R.E., 1995. Risks of exotic pest introductions from importation of fresh Mexican Hass avocados into the United States: an analysis by the University of California Center for Exotic Pest Research of USDA-APHIS Proposed Rule 7 CFR part 319, Docket No. 94-116-3. College of Natural and Agricultural Sciences, University of California, Riverside.

Mound, L.A., Marullo, R., 1996. The Thrips of Central and South America: An Introduction (Insecta: Thysanoptera). Associated Publishers, Gainesville.

Mound, L.A., zur Strassen, R., 2001. The genus Scirtothrips (Thysanoptera: Thripidae) in Mexico: a critique of the review by Johansen \& Mojica-Guzmán (1998). Folia Entomologica (Mexico) 40, 133142.

Nakahara, S., 1995. Taxonomic studies of the genus Tetraleurodes (Homoptera: Aleyrodidae). Insecta Mundi 9, 105-150.

Nakahara, S., 1997. Scirtothrips perseae (Thysanoptera: Thripidae), a new species infesting avocado in southern California. Insecta Mundi 11, 189-192.

Phillips, P.A., 1997. Managing greenhouse thrips in coastal avocados. Subtropical Fruit News 5, 1-3.

Popenoe, F.O., 1915. Varieties of the avocado. Report of the First Semi-Annual Meeting of the California Avocado Commission, vol. 1, pp. 44-69.

Rose, M., DeBach, P., 1990. Foreign exploration and importation of natural enemies. In: Rosen, D. (Ed.), The Armored Scale Insects, Their Biology, Natural Enemies and Control, vol. B. Elsvier, Amsterdam, pp. 417-431.

Rose, M., Woolley, J.B., 1984. Previously imported parasite may control invading whitefly. California Avocado Society Yearbook 68, 127-131.

Rosen, D., DeBach, P., 1992. Foreign exploration: the key to classical biological control. Florida Entomologist 75, 409-413.

Sakimura, K., O’Neil, K., 1979. Frankliniella, redefinition of genus and revision of minuta group species (Thysanoptera: Thripidae). USDA Technical Bulletin 1572, 1-48.

Scora, R.W., Bergh, B., 1990. The origins and taxonomy of avocado (Persea americana) Mill. Lauraceae. Acta Horticulturae 275, 387394.

Storey, W.B., Bergh, B., Zentmyer, G.A., 1986. The origin, indigenous range, and dissemination of the avocado. California Avocado Society Yearbook 70, 127-133. 
Tuttle, D.M., Baker, E.W., Abbatiello, M.J., 1976. Spider mites of Mexico (Acari: Tetranychidae). International Journal of Acarology 2, 1-108.

Van Driesche, R.G., Bellows Jr., T.S., 1996. Biological Control. Chapman \& Hall, New York.
Williams, L.O., 1977. The avocados, a synopsis of the genus Persea, subg. Persea. Economic Botany 31, 315-320.

Wilson, T.H., 1975. A monograph of the subfamily Panchaetothripinae (Thysanoptera). Memoirs of the American Entomological Institute 23, 1-354. 